\title{
Elektroerozyjne i wodne cięcie materiałów
}

\author{
Wire electrical discharge \\ and water jet machining of structural materials
}

\section{Streszczenie}

W artykule przedstawiono dwa sposoby wycinania skomplikowanych kształtów. Pierwszym z prezentowanych procesów jest wycinanie elektroerozyjne (Wire Electrical Discharge Machining - WEDM). Omówiono podstawy fizyczne, wpływ parametrów na przebieg procesu oraz własności użytkowe. Podano wady i zalety tego sposobu obróbki. Drugim sposobem przedstawionym $w$ artykule jest wycinanie strugą wody i wycinanie strugą wody ze ścierniwem (Water Jet Machining - WJM i Abrasive Water Jet Machining - AWJM). Podobnie jak przy omawianiu WEDM podano podstawy fizyczne, wpływ parametrów na przebieg procesu oraz własności użytkowe. Podano wady i zalety tego sposobu obróbki. W obu obróbkach przytoczono przykłady zastosowań.

Słowa kluczowe: wycinanie elektroerozyjne, WEDM, cięcie strugą wody, WJM, AWJM

\section{Abstract}

Two ways of shaping complex parts have been outlined in this paper. The first one, the Wire Electrical Discharged Machining (WEDM) has been presented by discussing its physical foundations, the performance features and the effect of machining parameters on the process course. The advantages as well as disadvantages of this process have been listed. The other method, Water Jet Machining (WJM) and Abrasive Water Jet Machining (AWJM) has been presented the similar way, by discussing its physical foundations, the performance features and the effect of machining parameters on the process course. The advantages as well as disadvantages of this process have been listed. The possible applications have been given for both machining methods.

Keywords: wire electrical discharge machining, WEDM, water jet machining, WJM, AWJM

\section{Wycinanie elektroerozyjne drutem - WEDM}

W obróbce elektroerozyjnej do kształtowania materiału wykorzystuje się kontrolowane wyładowanie elektryczne w cieczy dielektrycznej. Obróbka elektroerozyjna jest bardzo złożonym procesem i trudnym do opisania pod względem fizycznym, a co za tym idzie i matematycznym. W skrócie ogólny model fizyczny wyładowania elektrycznego można przedstawić następująco. Po przyłożeniu napięcia do elektrod powstaje niejednorodne i zmienne w czasie pole Elektryczne o natężeniu rzędu $10^{5} \div 10^{6} \mathrm{~V} / \mathrm{cm}$. Niejednorodność pola elektrycznego wywołana jest nierównościami powierzchni elektrod (np. chropowatość powierzchni), nierównomiernością grubości szczeliny międzyelektrodowej, niejednorodnością własności dielektryka oraz obecnością produktów obróbki w dielektryku. W miejscach gdzie natężenie pola elektrycznego jest największe, następuje koncentracja cząstek zanieczyszczeń dielektryka (głównie produktów erozji z poprzednich wyładowań), co obniża lokalną wytrzymałość elektryczną medium. Przy dostatecznym natężeniu pola elektrycznego i pewnym napięciu Ug, zwanym granicznym, następuje przebicie prowadzące do powstania kanału plazmowego. Wydzielające się ciepło, powoduje lokalne topienie lub/i parowanie materiału elektrod, który częściowo zostaje wyrzucony do dielektryka, a częściowo krzepnie w kraterze powstałym w wyniku tego wyładowania. Proces powtarza się, w najbardziej dogodnym miejscu, w takt impulsów podawanych z generatora napięcia (rys. 1).

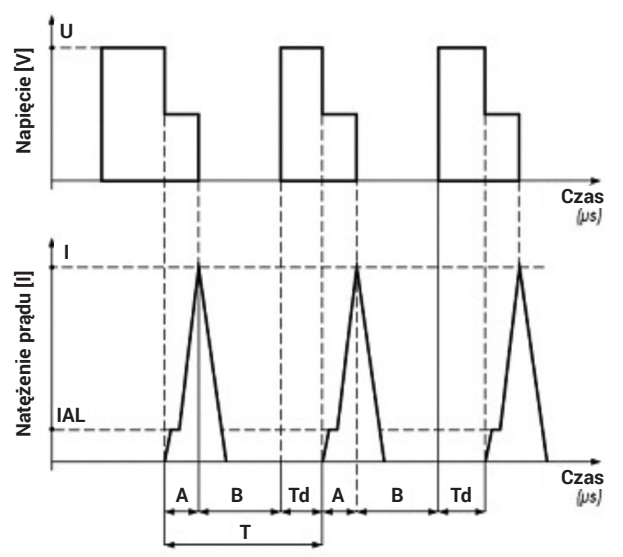

Rys. 1. Przykład impulsów napięciowych(U) i prądowych (I) stosowanych w obrabiarkach elektroerzyjnych

Fig. 1. Sample voltage (U) and amperage (I) waveforms applied for the electrical discharge machine generators

W wycinaniu elektroerozyjnym elektrodą (narzędziem) jest cienki jednorodny drut o średnicy $0.02-0.5 \mathrm{~mm}$ wykonanym z mosiądzu, miedzi, wolframu, molibdenu lub drut z pokryciem, np. mosiądz ocynkowany. Przedmiot obrabiany mocowany jest na stole obrabiarki, który najczęściej jest nieruchomy (masa obrabianych elementów może dochodzić kilku ton) natomiast drut przemieszczany jest w kierunkach wzajemnie prostopadłych przez układy napędowe sterowane numerycznie (rys. 2 b). Stosowane są również układy z ruchomym stołem (niewielkie części) i nieruchomymi prowadnikami drutu (rys. 2a). Nadając przedmiotowi i elektrodzie

Dr hab. inż. Marek Rozenek, prof. nzw. PW - Instytut Technik Wytwarzania, Politechnika Warszawska. 
(drutowi) złożone ruchy względne (postępowe i kątowe) możliwe jest wycinanie bardzo skomplikowanych kształtów. Wycinać możemy kształty o powierzchniach prostopadłych do powierzchni stołu, jak i pochyłych oraz bardziej złożonych pod warunkiem, że są to powierzchnie prostokreślne. Ze względu na zużycie erozyjne, drut jest przewijany ze szpuli do pojemnika lub ze szpuli na szpulę z prędkościami 0.5-20 m/min. Dla zapewnienia wysokiej dokładności pozycjonowania drutu względem przedmiotu obrabianego stosowane są specjalne oczkowe prowadniki drutu oraz stały naciąg drutu z siłą $5 \div 20 \mathrm{~N}$.

W WEDM najczęściej stosowanym dielektrykiem jest woda dejonizowana o przewodności elektrycznej poniżej $15 \mu \mathrm{S} / \mathrm{cm}$. W obrabiarkach stosowane są najczęściej trzy systemy podawania dielektryka: zanurzeniowy, zanurzeniowo wtryskowy oraz wtryskowy. W systemie wtryskowym, dielektryk podawany jest ze specjalnych wymiennych dysz (konstrukcja zależna od kształtu wycinanego przedmiotu) pod ciśnieniem do 1.5 MPa. System ten umożliwia uzyskanie szybkości cięcia do ok. $400 \mathrm{~mm}^{2} / \mathrm{min}$. Zaznaczone na rysunku 3 zużycie elektrody w praktyce jest pomijane, kompensowane jest ono szybkością przewijania drutu.
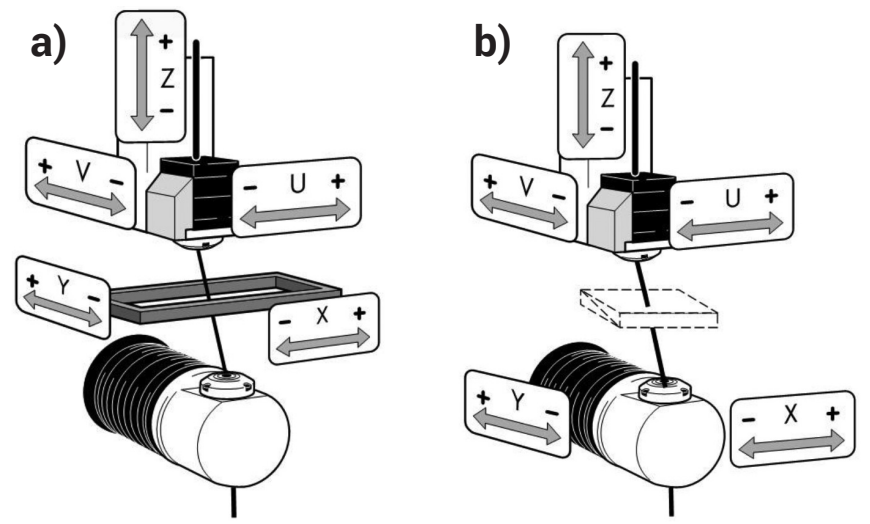

Rys. 2. Wycinanie elektroerozyjne drutem; a) z ruchomym stołem i górnym prowadnikiem drutu, b) stół nieruchomy, sterowany dolny $(x, y)$ i górny $(u, v, z)$ prowadnik drutu

Fig. 2. Wire electrical discharge machining a) with movable table and the upper wire guide b) fixed machining table, controllable lower $(\mathrm{X}, \mathrm{Y})$ and upper $(\mathrm{U}, \mathrm{V}, \mathrm{Z})$ guides

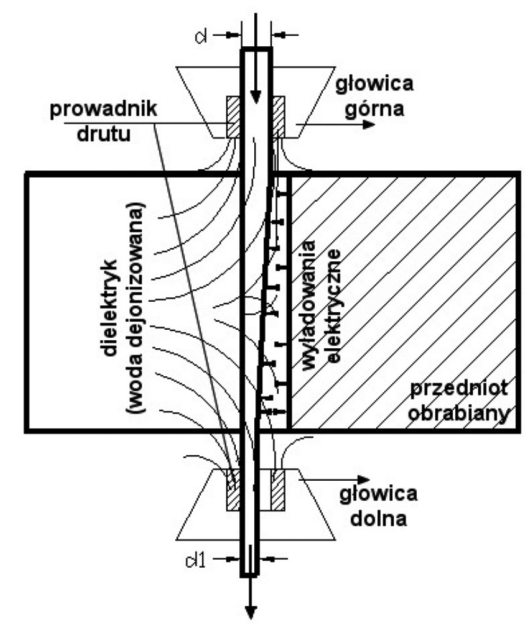

Rys. 3. Schemat wycinania elektroerozyjnego WEDM

Fig. 3. Diagram of wire electrical discharge WEDM

Proces wycinania rozpoczyna się od momentu, kiedy elektroda robocza (drut) zbliży się na odległość zapewniającą osiągnięcie natężenia pola elektrycznego większego od granicznego - od tego momentu zaczyna się formowanie szczeliny czołowej (rys. 4a). W miarę upływu czasu szczelina czołowa powiększa się (rys. $4 a$ i $4 b$ ), proces ten trwa do momentu, kiedy elektroda nie zagłębi się w materiał na głębokość równą połowie grubości drutu (głębokość wycięcia równa jest połowie średnicy drutu plus wartość szczeliny czołowej. Od tej chwili zaczyna się formować szczelina boczna (zwana dalej szczeliną). Wartość tej szczeliny zależna jest od takich czynników jak: odporność elektroerozyjna materiału, energia impulsu elektrycznego, przewodność elektryczna dielektryka, prędkość wycinania (posuw), naciąg i szybkość przewijania drutu, ciśnienie dielektryka. Należy dążyć do tego by w trakcie procesu te wielkości były stałe (będą wpływać na dokładność wykonania części).

$\mathrm{Na}$ rysunku 4c zaznaczono obszar szczeliny asymptotycznej, czyli maksymalnej szczeliny, jaka może powstać przy maksymalnych dopuszczalnych parametrach. Parametry technologicznie muszą być tak dobrane, by spieniały następujące kryteria: maksimum wydajności, maksimum dokładności, wymagania chropowatości. Kryteria te z natury obróbki elektroerozyjnej są sprzeczne, lecz możliwe do zrealizowania. Jak widać na rysunku 4c szczelina nie jest szczeliną asymptotyczną. W tym przypadku decydującym kryterium jest wydajność obróbki przy możliwie najmniejszych błędach, i tak dobiera się relację pomiędzy energią wyładowania elektrycznego i posuwem drutu, by te kryterium było spełnione, w wyniku, szczelina nie jest szczeliną asymptotyczną. W przypadkach, gdy obrabiarka nie jest w stanie utrzymać założonej stałej wartości szczeliny, układ sterowania musi dokonać korekcji parametrów obróbki, najczęściej jest to czas przerwy między generowanymi impulsami elektrycznymi. Pozostałe wymienione kryteria zostaną spełnione (jeśli jest to wymagane) w następnych operacjach wykańczających WEDM. Podczas wycinania należy dążyć do tego by szczelina iskrowa miała stałą wartość, i dotyczy to nie tylko powierzchni zewnętrznych, ale też każdego przekroju prostopadłego do osi drutu. Częstym błędem obróbki jest powstawanie baryłkowatości powierzchni (lub wklęsłość powierzchni obrabianej), pokazanej na rysunek 4d, linią przerywaną. Powstanie tego błędu ma szereg przyczyn.

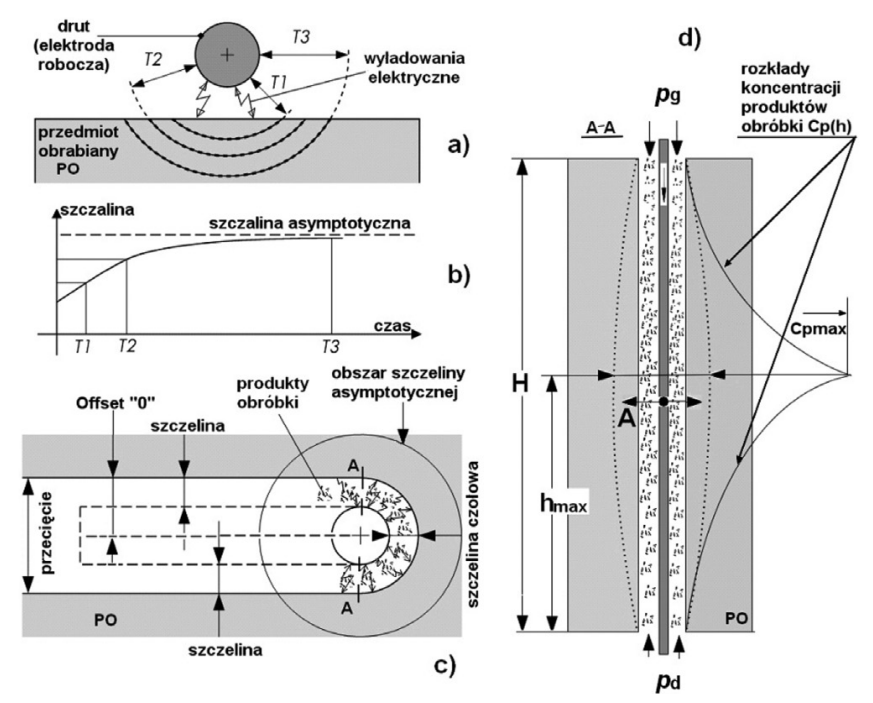

Rys. 4. Proces kształtowania się szczeliny międzyelektrodowej Fig. 4. The inter-electrode gap shaping process

Pierwszą przyczyną powstawania błędów kształtu są drgania drutu o amplitudzie A. Amplituda ta zależy przede wszystkim od:

- nierównomierności ciśnienia podawanego dielektryka (strugi) w szczelinie, która może być spowodowana: różnicą ciśnień pd i pg, występowaniem produktów obróbki w szczelinie, położeniem wycinanego kształtu - wycinanie na brzegu przedmiotu powoduje "ucieczkę" dielektryka na boki,

- drgań wywołanych wyładowaniami elektrycznymi w szczelinie,

- wysokości ciętego przedmiotu.

Amplitudę drgań można zmniejszyć przez zwiększenie naciągu drutu, jednakże należy pamiętać, że zwiększenie naciągu może prowadzić do zerwania drutu (powstawanie kraterów 
i mikropęknięć podczas procesu). W niektórych przypadkach, w których wymagana jest bardzo duża dokładność stosowane są specjalne elektrody z rdzeniem o wysokiej wytrzymałości, pozwalające na zwiększenie siły naciągu i zminimalizowanie w ten sposób drgań drutu. Nadmienić należy, że są to elektrody kilkakrotnie droższe od standardowych.

Drugą istotną przyczyną powstawania błędów jest występowanie produktów obróbki w szczelinie międzyelektrodowej. Z badań literaturowych [3,4], jak i badań własnych $[1,5 \div 8]$ wynika, że wpływ cząstek specjalnie dodanych do dielektryka lub pozostających w dielektryku jako produkt erozji materiału obrabianego wpływa w pewnym zakresie parametrów procesu na zwiększenie wydajności obróbki elektroerozyjnej i zmniejszenie chropowatości powierzchni obrabianej. Z oszacowań J. Kozaka [2] wynika, że cząstka znajdująca się w dielektryku i przewodząca prąd elektryczny wprowadza lokalnie 3 krotne zwiększenie natężenia pola elektrycznego. W przypadku cząstki nieprzewodzącej prądu elektrycznego zmiany te wynoszą 3/2 raza, ale też są znaczące.

W wyniku wyładowań elektrycznych pomiędzy narzędziem (drutem) a przedmiotem powstaje przecięcie w wymiarze nieco większym od średnicy drutu (od kilku do kilkudziesięciu mikrometrów). Połowa różnicy pomiędzy średnica drutu a wymiarem przecięcia nazywamy szczeliną boczną, natomiast wymiar od środka drutu do granicy przecięcia "Offsetem 0" (rys. 5).

Proces projektowania technologii WEDM rozpoczyna-
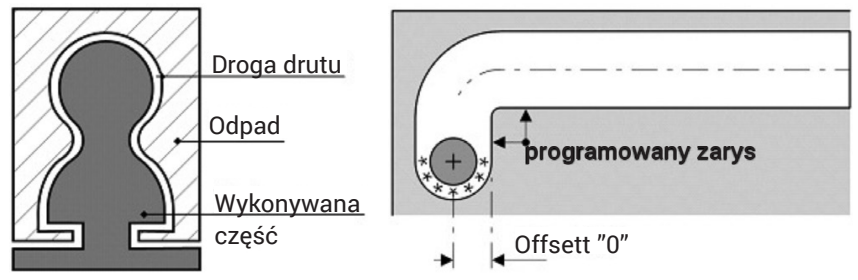

Rys. 5. Droga narzędzia podczas wycinania oraz podstawowe parametry geometryczne

Fig. 5. Path of the wire during the WEDM process and the basic geometry parameters

my od analizy tolerancji, jakości powierzchni wycinanego kształtu i kosztów wycinania. W zależności od dokładności i jakości powierzchni, kątów pochylenia profilu wycinanie przebiega w kilku przejściach (standardowo od 1 do kilku). Dla każdego przejścia ustalane są inne parametry wycinania (zmniejszająca się energia impulsu, rys. 6). Na dobór parametrów obróbki mają wpływ: materiał obrabiany, jego wysokość, własności drutu, własności dielektryka.

We współczesnych obrabiarkach WEDM parametry za-

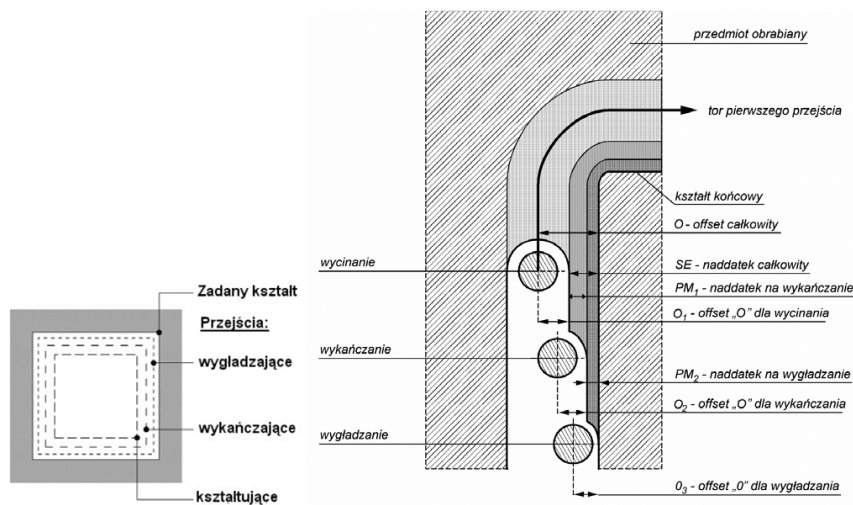

Rys. 6. Przykład cięcia w trzech przejściach: wycinanie, wykańczanie i wygładzanie

Fig. 6. Wire offset for three machining passes: basic cutting, finishing and polishing

dajemy dobierając odpowiednie tablice technologiczne zawarte w pamięci obrabiarki. W tablicach tych znajdują się informacje, które umożliwiają otrzymanie żądanego kształ- tu z określoną dokładnością i chropowatością powierzchni. W tablicach technologicznych znajdują się informacje dotyczące parametrów obróbki:

- charakteru impulsów,

- polaryzacji (biegunowość elektryczna elektrody) i napięcia w impulsie,

- natężenia prądu roboczego $\mathrm{w}$ impulsie,

- czasu impulsu roboczego,

- czasu przerwy między impulsami,

- czasu impulsu wstępnego,

- offsetów. Do podstawowych cech WEDM należą:

- uniwersalność elektrody, a więc wyeliminowanie konieczności wykonania elektrod o złożonych kształtach,

- eliminacja konieczności uwzględniania zużycia elektrody roboczej przy projektowaniu procesu obróbki,

- możliwość wykonywania skomplikowanych kształtów i o bardzo małych wymiarach,

- wysoka elastyczność produkcyjna obrabiarki,

- wysoki stopień automatyzacji z zastosowaniem sterowania numerycznego,

- eliminacja niebezpieczeństwa pożaru oraz poprawa warunków BHP, ze względu na stosowanie (najczęściej) jako dielektryka - wody,

- możliwość wykonywania części o profilu ekwidystanty przy zastosowaniu jednego programu dla układu NC, np. matryc, wykrojników, stempli, prowadników itp.,

- wysoka dokładność obróbki (od \pm 0.02 do $\pm 0.001 \mathrm{~mm}$ ),

- konieczność zastosowań małych energii wyładowań (poniżej $5 \mathrm{~mJ}$ ), uwarunkowanych małą średnicą drutu (dla uniknięcia zerwania) powoduje, że uzyskiwana jest wysoka gładkość ( $R a=2.5-0.32 \mu \mathrm{m})$, a zmiany w warstwie wierzchniej są nieznaczne (np. dla stali 1.2201 po cięciu zgrubnym grubość warstwy zmienionej jest mniejsza od $0.02 \mathrm{~mm}$ ),

- wysokość ciętego elementu do $400 \mathrm{~mm}$,

- możliwość obróbki materiałów trudnoobrabialnych innymi metodami,

- duża wydajność, zwłaszcza przy obróbce materiałów trudnoobrabialnych (do $400 \mathrm{~mm}^{2} / \mathrm{min}$ ).

WEDM ma również kilka wad i ograniczeń, np.:

- powstawanie warstwy wierzchniej o zmienionej strukturze w stosunku do ciętego materiału,

- proces jest energochłonny i drogi,

- ograniczenie wycinania do powierzchni prostokreślnych,

- możliwość obróbki tylko materiałów przewodzących prąd elektryczny.

Zastosowanie: wycinanie złożonych kształtów w materiałach trudnoobrabialnych, idealny sposób do wycinania elementów w wykrojnikach - jak płyta tnąca (zarys główny, otwory pod słupy - w jednym zamocowaniu) i stempel - jedna technologia (zarys wycinany, parametry obróbki), otwory w matrycach, formach odlewniczych i wtryskowych, koła zębate o dowolnym zarysie, itp.

\section{Obróbka strugą wody - WJM, AWJM}

W praktyce najczęściej stosowane są dwie odmiany obróbki strugą wody: czystą strugą wody (WJM) oraz strugą wody z dodatkiem ziarna ściernego (AWJM).

Zasadniczym warunkiem stosowania strugi wodnej do obróbki różnych materiałów jest uzyskiwanie na wylocie z dyszy strugi o właściwościach hydrodynamicznych, zapewniających zadowalającą efektywność procesu obróbkowego. Powszechnie przyjętym kryterium oceny hydrodynamicznych właściwości strugi jest jej koherentność, czyli zdolność do nie rozpadania się podczas ruchu i zachowania swojej energii kinetycznej do jak najdłuższej odległości od dyszy. 
Wysokociśnieniowy strumień wody przy wylocie z dyszy trafia na powietrze tj. ośrodek o gęstości około 800 razy mniejszej od wody. W takich warunkach zewnętrzne części strugi wodnej oddzielają się od jej podstawowej masy interferując z przylegającymi warstwami powietrza, o mniejszej prędkości ruchu. Niejednokrotnie też powietrze z otaczającego środowiska wdziera się do wnętrza tychże zewnętrznych warstw strugi wodnej. Wszystko to prowadzi do narastającej, wraz z odległością od dyszy, wymiany masy pomiędzy płynem z wysokociśnieniowej strugi a otaczającym powietrzem. Powoduje to nieciągłości w strukturze strugi wodnej i częściowe jej rozkropelkowanie, które ulegając dalszemu rozdrobnieniu prowadzi do rozszerzania się strugi, co ułatwia jej rozpływ po powierzchni materiału obrabianego. Takie nasycenie strugi wodnej powietrzem, zwane aeracją strumienia, zaczyna się od powierzchni strugi i sukcesywnie przenika do jej wnętrza. W takich warunkach zaczyna wyodrębniać się rdzeń strugi, w którym transportowana jest główna część jej energii. Walcowa początkowo struga wodna odkształca się przyjmując zwykle postać stożka. Narastająca wraz z odległością od dyszy aeracja strugi sprawia, że w końcowej strefie jest ona mieszaniną oddzielnych, aczkolwiek jeszcze uwarstwionych cząstek wody i powietrza. Prowadzi to do zmniejszania się prędkości strugi wraz z jej odległością od dyszy oraz ciągłego powiększania jej średnicy. W tym obszarze wartości prędkości poosiowej oraz nacisku strugi są już niewielkie, zbliżając się asymptotycznie do wartości zerowych [9].

Szczególnie duży gradient prędkości występuje w płaszczyźnie prostopadłej do osi strugi, zwłaszcza zaś w strefie jej styku z powietrzem. Na styku bowiem poruszającego się naddźwiękowego strumienia wody z otaczającym go, lecz pozostającym w spoczynku powietrzem istnieje bardzo duża różnica prędkości. W związku z tym w kierunkach promieniowych względem osi strugi powstają duże siły aerodynamiczne, które są proporcjonalne do tej różnicy prędkości. Wszystko to powoduje nierównomierny rozkład masy strugi, co się pogłębia w miarę oddalania od dyszy. W ogólnym zarysie omówiony powyżej model strugi wodnej obowiązuje także i dla wysokociśnieniowego strumienia wodno-ściernego. Zwykle bowiem objętość ścierniwa domieszkowanego do strugi wodnej stanowi stosunkowo niewielki udział. Dotyczy to zwłaszcza warunków tworzenia strugi wodno-ściernej używanej do czyszczenia powierzchni technicznych. Objętościowa zawartość ścierniwa w strudze wynosi zwykle ok. 1\%, mało kiedy osiągając poziom kilku procent. Jednak uciążliwość warunków mieszania ziaren ściernych ze strugą wody w normalnie stosowanych głowicach roboczych (rys. 7) sprawia, że już w początkowej fazie przyspieszania ziaren, co najmniej kilkanaście do $80 \%$ spośród nich ulega rozkruszeniu zaś drugie tyle jest rozpraszane w zewnętrznych warstwach strugi wodnej. Powoduje to zwykłe turbulencje przepływu strugi oraz zakłócenia jej wewnętrznej struktury. Powoduje to zwiększe-

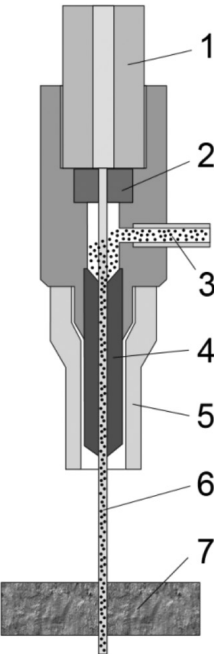
nie średnicy strumienia wodno-ściernego 1 w stosunku do analogicznego strumienia wodnego. 0 rozmiarach tych zakłóceń decyduje sposób mieszania ścierniwa ze strugą 2 wodną. Sposób mieszania wywiera zasadniczy wpływ na rozkład ziaren ściernych w przekroju strugi wodno-ściernej.

Rys. 7. Głowica robocza: 1 - dopływ wody pod 4 wysokim ciśnieniem, 2 - dysza wodna z osadzonym diamentem lub rubinem, 3 - materiał ścierny (granat), 4 - dysza mieszająca, 5 - osłona, 6 - strumień tnący, 7 - cięty materiał

6 Fig. 7. WJM operation head: 1- high pressure water influx, 2- water nozzle with the embedded diamond or ruby eyelet, 3 - abrasive material (mostly garnet), 4- blending nozzle, 5 - cover, 6 - water jet, 7 - material to be cut
Wiele spośród ziaren doprowadzanych w strefę mieszania w ogóle nie jest w stanie dostać się do wnętrza "twardej” strugi wysokociśnieniowej. Charakter rozkładu ziaren ściernych w strudze wywiera istotny wpływ na ukształtowanie i erozyjną skuteczność strugi wodno-ściernej. Dlatego też cechy te mogą być decydujące dla przydatności strugi wodno-ściernej do efektywnego jej wykorzystania [9]. Największe ilości ziaren ściernych przepływają w osi strugi wodno-ściernej, gdzie panuje najmniejsze ciśnienie całkowite. W miarę zaś oddalania się od osi strugi natężenie przepływu ziaren ulega zmniejszeniu. Najmniejsze ilości ziaren występują w zewnętrznych warstwach strugi, w których panuje największe ciśnienie. Stwierdzono przy tym, że zwiększenie liczby otworów w koncentrycznej dyszy tryskacza wywołuje wzrost natężenia przepływu ziaren ściernych [11].

Mechanizm obróbki materiałów przy użyciu strumienia wody o wysokim ciśnieniu (z prędkością rzędu kilkuset metrów na sekundę) jest bardziej złożony od obróbek konwencjonalnych i ma swoje specyficzne cechy. Podczas obróbki wodno-strumieniowej, w rezultacie lokalizacji naprężeń niszczących w obszarze małych objętości i dzięki dużej prędkości przyłożenia obciążenia, od podstawowej masy materiału odrywane są bardzo małe cząstki (mikrowiórki) o różnorodnych kształtach. Mechanizm tej obróbki nie jest w pełni znany.

Jednym z najważniejszych zespołów obrabiarki do ciecia strugą wody jest pompa dostarczająca strugę wody do przedmiotu obrabianego. Współczesne wysokociśnieniowe systemy cięcia wyposażone są w hydrauliczne pompy ze wzmacniaczem (rys. 8) lub pompy z wałem korbowym.

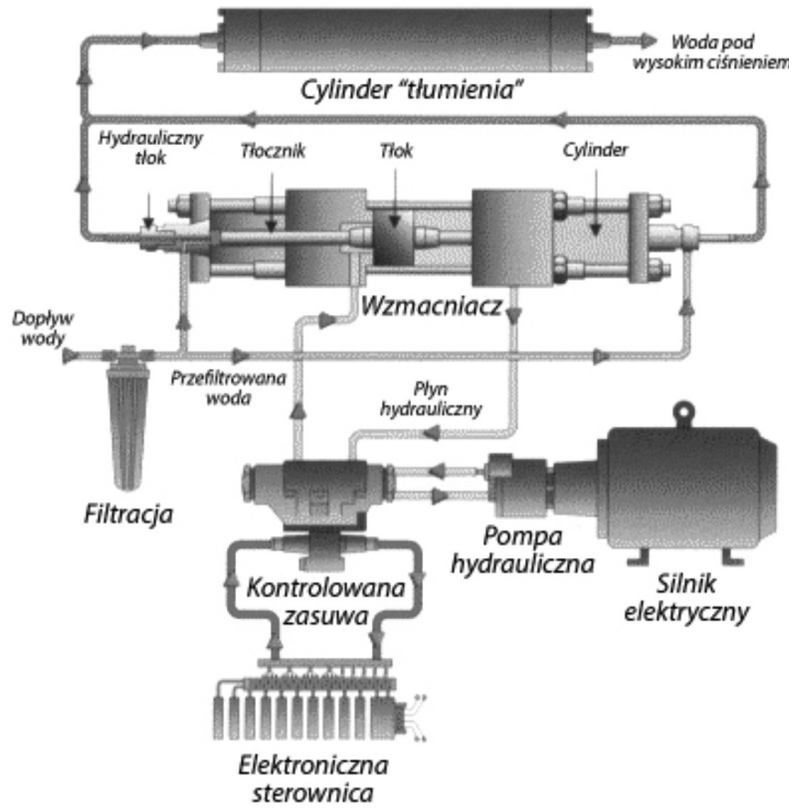

Rys. 8. Schemat pompy hydraulicznej ze wzmacniaczem [12] Fig. 8. Hydraulic pump with single fluid amplifier [12]

Zasada działania pompy ze wzmacniaczem polega na tym że silnik elektryczny napędza pompę hydrauliczną, która pompuje płyn hydrauliczny pod ciśnieniem od 6,9 do 27,6 MPa do cylindra wzmacniacza. Ciśnienie hydrauliczne działa na stosunkowo duży tłok, by wytworzyć dużą siłę na tłocznik o stosunkowo małej średnicy. Ten tłocznik podnosi ciśnienie wody do poziomu, który jest proporcjonalny do odpowiednich pól przekroju poprzecznego dużego tłoka i małego tłocznika. Cylinder wzmacniacza jest cylindrem obustronnego działania, w którym płyn hydrauliczny jest wprowadzany na przemian z jednej i drugiej strony. Hydrauliczny tłok na przemian zwiększa ciśnienie wody przez tłoczniki małej średnicy na każdym końcu zespołu wzmacniacza. Chodzący tam i z powrotem tłok wzmacniacza powoduje pulsujący przepływ wody pod bardzo wysokim ciśnieniem. By uczynić przepływ wody bardziej jednolitym (w ten sposób 
wpływając na gładsze cięcie), pompa wzmacniacza jest zazwyczaj wyposażona w cylinder „tłumienia”, który działa jako wysokociśnieniowe naczynie wyrównawcze [12].

W pompach z wałem korbowym wykorzystuje się mechaniczny wał korbowy, który porusza w cylindrze tam i z powrotem napędzając dowolną liczbę pojedynczych tłoków lub tłoczników. Zawory zwrotne w każdym cylindrze pozwalają wodzie wejść do cylindra, gdy tłocznik cofa się i opuścić cylinder do rozgałęzionego przewodu wylotowego, gdy tłocznik posuwa się naprzód w cylindrze.

Pompy z wałem korbowym są bardziej wydajne niż pompy ze wzmacniaczami, ponieważ nie wymagają zastosowania, zużywającego duże ilości energii, systemu hydraulicznego. Dodatkowo, pompy z wałem korbowym o trzech lub więcej cylindrach mogą być tak zaprojektowane, by dostarczały bardzo jednorodne ciśnienia na wyjściu. Dzisiaj pompy z wałem korbowym mogą pracować niezawodnie aż do ciśnienia 380 $\mathrm{MPa}$. Doświadczenie pokazało, że strumień materiału ściernego tak naprawdę nie potrzebuje bardzo wysokiego ciśnienia, uzyskiwanego z pompy ze wzmacniaczem. W tego typu maszynach tak naprawdę materiał, tnie ścierniwo, podczas gdy woda działa jedynie jako medium do jego przenoszenia przez materiał, który jest cięty.

Za formowanie strugi hydrościernej i ostateczne jej przyspieszanie odpowiada dysza (o średnicy otworu kształtującego $0.18-0.4 \mathrm{~mm}$ ). Wewnętrzne ścianki dyszy podlegają intensywnej erozji przez ścierniwo, rozpędzone do dużej prędkości. Z tej racji dysza jest elementem najbardziej narażonym na erozyjne oddziaływanie strugi hydrościernej. Intensywność zużycia dyszy zależy przede wszystkim od właściwości ścierniwa oraz wielkości hydraulicznych. Wśród własności ścierniwa największy wpływ na zużycie dyszy mają: zdolność skrawna, gęstość oraz wielkość i kształt ziaren. Najważniejszymi właściwościami dyszy są: materiał, z którego dysza jest wykonana (najczęściej z szafiru lub rubinu, diamentu) oraz jej kształt. Decydujące zaś wielkości hydrauliczne to wydatek ścierniwa oraz prędkości strugi, będącej wynikiem oddziaływania ciśnienia [9].

Najczęściej stosowanym ścierniwem w obróbce strugą wody jest granat (o wielkość ziarna od 60 do 120, najczęściej 80). Najlepsze własności skrawne wykazuje elektrokorund, jednakże powoduje on prawie 50 krotnie większe zuży- cie dyszy niż granat [9].

Podstawową wadą obróbki strugą wody jest powstawanie tzw. stożka. Termin "stożek" odnosi się do ukośnych krawędzi materiału, które powstają podczas cięcia strumieniem wodnym lub strumieniem wodnym z materiałem ściernym. Typy stożków to: stożek w kształcie litery v, stożek odwrócony, stożek baryłkowaty stożek romboidalny lub trapezowy. Na wielkość i typ stożka najbardziej wpływa grubość materiału i obrabialność. Najefektywniejszym sposobem minimalizacji stożka jest zastosowanie głowicy sterowanej w trzech osiach (3D).

Klasyczną obróbką strugą wody (sama woda) można ciąć takie materiały jak: miękka guma, pianka, folia, tkaniny, miękkie wykładziny PCV, papier i tektura, miękkie lub cienkie drewno, żywność, wszystkie inne rodzaje materiałów o małej twardości.

Stosując strugę wodno-ścierną można ciąć: stale, metale kolorowe, ceramikę włókna węglowe, tworzywa sztuczne, materiały wybuchowe, kompozyty.

W praktyce grubość przecinanej stali wynosi do $20-30 \mathrm{~mm}$, aluminium nawet do $300 \mathrm{~mm}$, tytanu nawet do $150 \mathrm{~mm}$.

Zalety wycinania strugą wody to:

- możliwość cięcia dowolnego materiału,

- uniwersalność narzędzia,

- brak strefy wpływu ciepła,

- bardzo małe naciski podczas procesu cięcia,

- wydajność cięcia,

- technologia przyjazna dla środowiska (woda),

- gospodarka odpadami (w wyniku obróbki uzyskujemy niewielki ślad przecięcia), ma to kolosalne znaczenie przy cięciu drogich materiałów,

- elastyczność produkcyjna,

- brak zadziorów na krawędziach, równe krawędzie, cięcie "pod kątem”,

- możliwość zastosowania tej metody do czyszczenia części. Wadami procesu są:

- żywotności głowic (maksymalnie do 140 godzin),

- stożkowatość ciętych powierzchni,

- różnice w chropowatość na powierzchni przeciętej części,

- mała wydajność.

- Dokładność wycinania strugą wody dochodzi do 0,1 mm, a chropowatość powierzchni (z zastosowaniem obróbki wykańczającej) do $1 \mu \mathrm{m} \mathrm{Ra.}$

\section{Wnioski}

Wycinanie elektroerozyjne jak i cięcie strugą wody pozwalają na kształtowanie części o dużej wysokości. Obie obróbki pozwalają na korzystne gospodarowanie odpadami (niewielki ślad po przejściu narzędzia). W WEDM możemy uzyskać wysoką dokładność, rzędu kilku mikrometrów (WJM do 0,1 mm). Wycinanie strugą wody nie powoduje zmian w strukturze materiału (w WEDM w wyniku oddziaływań termicznych dochodzi do zmian w warstwie wierzchniej). Obróbki charakteryzują się stosunkowo małą szybkością cięcia, stąd opłacalne jest wycinanie w materiałach trudnoskrawalnych lub/i przy kształtowaniu skomplikowanych zarysów.

\section{Literatura}

[1] Dabrowski L., Yu j., Kozak j., Rozenek M., Theoretical Analysis of Electric Field Distribution in EDM with Powder Mixed Dielectric, Proceed. of the 4th International Conference on Global Research and Education "Inter-Academia 2005", Vol. 1, Wuppertal, Germany, 2005.

[2] Kozak J., Rozenek M., Dąbrowski L., Badania wstępne obróbki elektroerozyjnej w dielektryku z ziarnami ściernymi, Prace naukowe Programu Priorytetowego Nowe Technologie, zeszyt 3, Oficyna Wydawnicza PW, Warszawa 2000

[3] Mohri N., Saito N., Nnarumiya H., kawatsu Y., Ozaki K. T. AND Kobayashi, K., Finish Machining by EDM Using Powder Suspended Working Fluids, Journal of JSEME, vol. 49. 1992.

[4] Mori N., Saito N., Narumiya H., Kawatsu Y., Otake H., Takawashi T. and Kobayashi K., Study on Finishing of Large Area Workpiece by EDM, Journal of the Japan Soc. for Prec. Eng., vol. 53, No. 1. 1987.

[5] Rozenek M., Kozak J., Dabrowski L., Study of Electrical Discharge Machining using Powder Suspended Working Media, Proceed. of the 13th International Symposium for Electromachining ISEM XIII, Bilbao, 2001.
[6] Rozenek M., Kozak J., Dabrowski J., Electrical Discharge Machining in Dielectric-Powder Media, Proceedings of the 2nd International Conference on Advances in Production Engineering APE-2, , Vol. II, Warsaw 2001.

[7] Rozenek M., Kozak J., Dabrowski L., Electrical Discharge Machining in Dielectric-Powder Media, International Journal for Manufacturing Science and Technology, Vol. 4, No.1, 2002.

[8] Rozenek M., Dąbrowski L., Obróbka elektroerozyjna w dielektryku z proszkami przewodzącymi, Monografia Zagadnienia konstrukcyjne i technologiczne niekonwencjonalnych technik wytwarzania, Wydawnictwo Akademii Techniczno-Rolniczej, Bydgoszcz, 2006.

[9] Borkowski P., Obróbka wysokociśnieniową strugą wodno-ścierną, Wydawnictwo Uczelniane Politechniki Koszalińskiej, Koszalin 2002.

[10] Perec A., Badania wybranych wielkości procesu obróbki wysokociśnieniową strugą hydrościerną, XXI Naukowa Szkoła Obróbki Ściernej Warszawa-Miedzeszyn, 1998.

[11] Borkowski P., Efektywność obróbki powierzchni wysokociśnieniową strugą wodno-ścierną, Mechanik Nr 2/2005.

[12] http://www.jetsystem.pl/ 